\title{
ISLAMIC PARTY SURVIVES IN 2014 LEGISLATIVE ELECTION? (THE CASE OF PKS)
}

\author{
Ahmad Ali Nurdin \\ Faculty of Social and Political Sciences, \\ UIN Sunan Gunung Djati, Bandung
}

\begin{abstract}
This paper examines performances of PKS in the last 2009 election, West Java and DKI Jakarta gubernatorial elections and the current 2014 legislative election to answer whether PKS looses or survives their political support from Indonesian people in the 2014 election. Although the cadre of PKS is still solid compare to that of other parties, there are a variety of reasons why the popularity of PKS slightly declined in the 2014 election compared to that of 2009 election. The involvement of the former president of PKS, Luthfi Hasan Ishak, in the case of beef graft has lessened the confidence of Indonesian people to the integrity of PKS in eradicating corruption in Indonesia. Thus, many Indonesians have doubt and less confidence in the capacity of PKS to solve other national problems. In addition, the weak and the least possible figure of PKS to be nominated as a president candidate is another reason why PKS cannot become a champion in the 2014 presidential election. Looking at the quick count result done by several survey institutions, however, PKS is considered to be survived in the 2014 election. They successfully maintain and strengthen their cadres' solidity. Their leading figures were quite successful in rebuilding trust not only for their loyal cadres but also public in general that they are really 'clean' and 'professional' and ready to combat corruption in the country. PKS proved to the public that the case of their former president was 'the only corruption case' done by 'personally individual' (oknum) whom they will not tolerate.
\end{abstract}

\section{INTRODUCTION}

Indonesian general election has been conducted successfully on April 9, 2014. Some argue that 2013-2014 are 'years of politics' in which every political party not only contends to gain supports from the people but also 'captives' one another. In fact, the 2014 elections, both for the parliament and president, are very crucial. It is the fourth parliamentary election since 
the authoritarian Soeharto regime out of office, and the third direct election for president.

General Election Commission (KPU) has passed 12 political parties in a screening process that has seen the overall field drop from the 48 parties which took part in the first democratic elections in 1999 to 24 in 2004, and then back to 38 in 2009. Nine are the parties currently represented in the House of Representatives and the others three are the National Democrat Party (Nasdem), Crescent Star Party (PBB) and Indonesian Justice and Unity Party (PKPI). The nine parties in the House are the Democratic Party, Golkar Party, Indonesian Democratic Party of Struggle (PDI-P), Prosperous Justice Party (PKS), National Mandate Party (PAN), United Development Party (PPP), National Awakening Party (PKB), Great Indonesia Party (Gerindra), and People's Conscience Party (Hanura).

With only twelve parties contest and only four political parties considered to be Islamic, several analysts argue that because they will be less confused by the proliferation of choices, voters are able to pay closer attention to party policies. Thus, in this Indonesian vibrant emerging democracy, several questions remained unsolved: how were the Islamic political parties' performance in the election? Did Islamic political parties gain huge support from the people or conversely? These questions are important to be answered because several findings of survey institutions before the election have predicted the declining popularity of Islamic political parties in the coming election. Was their prediction correct and come to a reality?

Based on the above background, this paper tries to answer and prove whether Islamic political parties, particularly PKS, ended as predicted by survey institution or conversely. Does PKS still have a bright future in the coming presidential election? And what do the impacts of (declining or increasing Islamic parties) in the general election to the presidential election?

To answer the above questions, this paper firstly describes a solidity of PKS in maintaining their cadres. Some argue that PKS is the only true cadre party in the country. The discussion is followed by analyzing PKS's performance in the 2009 election, their performances in gubernatorial elections both in West Java and Jakarta provinces and their performance in 2014 election to measure whether PKS still has a chance to survive or even become a champion in the coming 2014 presidential election.

\section{MATERIALS AND METHODS}

This study was conducted prior to and one week post 2014 legislative election. While for the prior election, the data is based for the most part on interviews that have been conducted with main figures of political parties 
post 2009 election and after the gubernatorial elections in West Java and DKI Jakarta. To update the current 2014 election, the data was collected using quick count reports done by several survey institutions such as Lingkaran Survey Indonesia (LSI), Indikator Politik Indonesia (IPI), Cyrus Network-CSIS, Lembaga Survey Nasional (LSN) and Jaringan Survey Indonesia (JSI).

\section{RESULT AND DISCUSSION}

\section{A. Is PKS A Solid-Cadre Party?}

PKS declares itself as a dakwah ${ }^{1}$ and party of cadres. In an official document of the party, the first PKS President, Nur Mahmudi Ismail states:

PKS was established not only for dakwah mission but also proposed to be a vehicle for political education for Muslim and other Indonesians. Well organized, a disciplined and strict cadre training and sympathetic approaches to the community are main characteristics of the party. ${ }^{2}$

Ismail's statement above shows that PKS is not only a party of cadres as was claimed by Fealy, who says that PKS is the only true party of cadres in Indonesia. ${ }^{3}$ Anis Matta, the current Secretary General of PKS comments on the characteristics of his party saying that: "PKS adalah gabungan antara apa yang kita sebut dengan Nukhbawiyah Jamahiriyah, gerakan elit dan massa (PKS is a combination of what we call an elite and a mass movement)." "This means that PKS is a combination of cadre and mass party at the same time. PKS believes that in the process of the resurgence of the Islamic community, Muslims need a qualified, collective leadership. In this context, an Islamic party in Indonesia, like PKS, can play a role to train cadres to become qualified leaders trusted by the community to lead the country in the future. Matta says:

PKS holds a principle that a leader will perform well if he is supported by a strong mass base. If the relationship between elites and mass supporters is strong, it is hard for a political conspiracy to break cohesiveness between elites and their supporters because during the process of governing the state various challenges may occur. $^{5}$

\footnotetext{
${ }^{1}$ Dakwah or Islamic preaching literally means "to invite people." This is mainly intended to deliver Islamic teachings, like Quranic interpretations, Hadith (Prophet Muhammad's speech and acts) and Islamic laws to the people.

${ }^{2}$ Sekretariat Jenderal DPP PKS Bidang Arsip dan Sejarah, Sikap Kami: Kumpulan Sikap Dakwah Politik PK dan PKS Periode 1998-2005 (Bandung: Harakatuna Publishing, 2007), 122.

${ }^{3}$ See Fealy's argument in his preface to Yon Machmudi, Partai Keadilan Sejahtera: Wajah Baru Islam Politik Indonesia (Bandung: Harakat una, 2005), vi.

${ }^{4}$ Aay Muhamad Furkon, Partai Keadilan Sejahtera: Ideologi dan Praksis Politik Kaum Muda Muslim Indonesia Kontemporer (Jakarta: Teraju, 2004), 206.

${ }^{5}$ Furkon, Partai Keadilan Sejahtera, 206.
} 
As the party prepares qualified cadres to become leaders in the future, PKS's members must know the ideology of the party and cannot buy their way through a patronage network. PKS also has its own special cadre recruitment, training and selection process. This liqā' (weekly ideological gathering) training has resulted in a loyal and committed membership. This typology of party as dakwah and a cadre-based party is also confirmed by the former president of PKS, Hidayat Nur Wahid. Wahid also insists that although PKS is a cadre party, it is a non-sectarian and open party, which allows all Indonesian people, whatever his or her religious beliefs, to be eligible to become party members. He further says:

I should add one point. When I talk about the Indonesian people, I don't think only about Muslims. $\mathrm{PK}(\mathrm{S})$ is an open party. I have been on panels with various kinds of people: Catholic philosophers such as Franz Magnis-Suseno, Romo Mudji Sutrisno, and Muslim scholars like Cak Nur [late Nurcholish Madjid] and Hasyim Muzadi [Chairman of Nahdlatul Ulama] and others. Many Christian fellows have told me that they like $\mathrm{PK}(\mathrm{S})$. Some have even asked if they, as non-Muslims, can join $\mathrm{PK}(\mathrm{S})$. I've replied that $\mathrm{PK}(\mathrm{S})$ has never required its members to be Muslims. All it requires is that they are Indonesians and that they are over 17 years old. So, if Christians are interested they can join us. But they should realize that we are a cadre-based party, in which we have cadre programmes for our members. We will give them training. ${ }^{6}$

Wahid's argument that his party is open and non-sectarian could also be seen from the party's official platform. In its Anggaran Rumah Tangga, Partai Keadilan (before transforming itself to PKS) Chapter 2, article 8 about its membership, it explains seven requirements to become PKS members. None of these requirements restrict its members to only Muslims, or only males or only certain ethnic groups. The requirements to be party members are stated to be: (1) Indonesian citizens: male or female, (2) over 17 years old or married, (3) of good behavior, (4) in agreement with the party's objectives, (5), officially apply to became a party member to its headquarter office through Dewan Pimpinan Daerah (District Officers), (6) practicing and concern with membership obligations and (7) who declare to be loyal to the party's principles and platforms. ${ }^{7}$ After PK was transformed into PKS, the party's Anggaran Dasar Chapter 3, article 7, on memberships also says: "All Indonesian citizens who have fulfilled requirements and agreed with the party platform are eligible to become members of Partai Keadilan Sejahtera."

${ }^{6}$ Hidayat Nur Wahid, “Power Means Serving Others,” Van Zorge Report (March 18, 2002): 7.

${ }^{7}$ DPP Partai Keadilan Sejahtera, Sekilas Partai Keadilan Sejahtera (Jakarta: 1998), 64. 
Non-Muslim members and supporters are also well accommodated by PKS. This argument could be seen from the significant numbers of supporters who voted for PKS during the 2004 general election. According to a voter survey during the 2004 election period made by an Indonesian NGO, the Lembaga Penelitian, Pendidikan dan Penerangan Ekonomi dan Sosial (LP3ES), ${ }^{8}$ PKS supporters then were mostly young, middle-income, educated Muslims. Nearly 99 per cent of the PKS voters were Muslim, though the one percent of Hindu and Christian voters was a notable achievement for a party once so defined by its Islamist goals. With regards to a minority group, it is important to note here a statement from the current PKS President, Tifatul Sembiring when he was asked his opinion on minority groups:

If once PKS was given an opportunity to rule the country (Indonesia), PKS would shelter and protect all ethnic groups, not only Muslim. Because the prophet Muhammad has always said that whoever offends a person of a different faith will become my enemy in the hereafter. All citizens will have equal rights. It is even not a problem for PKS to have a non-Muslim president if he/she was elected democratically by Indonesian people. Since most of Indonesian people are Muslim, and through a direct presidential election, it is more likely that Muslim would be elected as president. ${ }^{9}$

Another surprising finding of the LP3ES survey above was that nearly 20 per cent of voters categorized their occupation as "housewife," a larger proportion than student voters. Evidently, the PKS platform for a clean and caring government, combined with the party's large percentage of female politicians, hit home with women voters. From these findings one also could argue that women's political interests are well accommodated by this PKS Islamic party. My direct observation as a participant in the protest rally held by PKS convinced me of the survey findings of LP3ES. It can be seen from the fact that more than half of the protestors were females who even brought their children. These mothers said that their children are the next generation of political activists.

The LP3ES survey above also showed that nearly 50 per cent of PKS voters were between the ages of 23 and 35, and the majority had a significantly higher level of education than the average supporter of other

\footnotetext{
${ }^{8}$ Lembaga Penelitian, Pendidikan dan Penerangan Ekonomi dan Sosial (LP3ES) or Institute for Social and Economic Research, Education \& Information is a Non-Government Organization (NGO), which is non-profit and autonomous. It was founded by a group of intellectuals and student activists on August 19, 1971. Its formation was sparked by the felt need for developing alternative thinking for national development. For more detail of this organization, see www.lp3es.or.id (accessed August 9, 2013).

${ }^{9}$ See Jawa Pos, July 26, 2005.
} 
Indonesian parties. On one occasion, Tifatul Sembiring (a current PKS President) stated that more than eighty per cent of PKS cadres hold university degrees. Yet, what was missing from Sembiring's statement was the fact that, based on my interviews with the members of PKS in the district levels like Depok, Bogor and Kuningan, I found that almost one hundred percent of the party's 'generators' were university students who actively build their network with students from the Senior High Schools in Indonesia. This party's core groups with their own style also influenced their parents and other family members to become PKS supporters in the election

The PKS believes that its future political success stems from today's younger generation. The quality of the cadres and their integration into the party are very important for PKS development. Thus, the selection of individuals is based on two main criteria: the ability to adapt to a concept of 'life-long education' and continual personal development, and on the ability to maintain a spiritual and truly Islamic dimension in political activism. An important part of the process of life-long education is the ability to accept constructive criticism and feedback from others as a way towards personal improvement. This means that in the PKS, every member is given equal opportunity to become the best members of the party and at the end they will be chosen as top candidates from the party for either national or local parliamentary elections. Because of the process of life-long education and training of the cadres in internal organization, the PKS could be seen as a party that initiated the transmission of democratic values into its constituents.

In the process of cadre training and recruitment, the PKS plays its role as a political party that educates its members on how the political and democratic rules should be followed to achieve their goals. In this matter, it could be argued that PKS functions as an agent of transmission of democracy's values to Indonesian people, or at least to their cadres and constituents. The PKS believes that integrated and well educated cadres, who understand the party platform, and the nature of political rules in Indonesia, might help to influence the Indonesian people in general to follow democratic rule. For PKS, to build Indonesia as a prosperous, developed and democratic country, it is necessary to start with the smallest unit of community that is the person as an individual. A good individual will lead to establish a good family. A good family will produce a good community and finally will create a good nation. Thus it could be argued that for PKS, the smallest unit of a nation or state is a person as an individual not villages-community as was commonly perceived by philosophers such as Aristotle. The official document of PKS says:

To have a qualified cadre, it is necessary to have a special and step by step training. Step by step training started with creating a strong 
individual because it will produce a good family. Good family will lead to create a good community. Good family and community will produce a good life environment. Because to establish a good state require good individuals and society that can be trusted to take responsibility to govern, creating a good and strong individual is necessary. ${ }^{10}$

PKS believes that to create a good nation should start from a small structure that is an individual then a family. This argument seems to be based on the Quranic verse that says:

Allah does not change a people's lot unless they change what is in their hearts. But when (once) Allah willeth a people's punishment, there can be no turning it back, nor will they find, besides Him, any to protect. ${ }^{11}$

The success of PKS in recruiting and training its cadre could be seen from the increasing number of its loyal cadres from only 33,000 in 1999 to 500,000 in 2004 and more than one million controllable cadres in 2009. Tifatul Sembiring (former president of PKS) says that his party's target is to have 2.5 million loyal cadres prior to the general election in 2014. This target is realistic because PKS has a very intensive cadre training and recruitment whose success has been proven. ${ }^{12}$

Intensive Cadre Training (Liqā') ${ }^{13}$

The history of PKS's establishment cannot be separated from early dakwah and tarbiyah movements in Indonesia back in the 1980s and 1990s. The dakwah movement in its early stage was only popular among university students and was known as the tarbiyah movement. However, it quickly spread among middle-class Indonesians, particularly after the alumni of tarbiyah groups in leading universities got their permanent jobs. They kept up their tarbiyah activities and recruitment in the places where they worked. One of the characteristics of this movement was the creation of a small discussion group (halaqah) consisting of five to twelve members, to study Islamic teaching intensively. This kind of group was very popular in leading secular universities in Indonsia such as Universitas Indonesia (UI Jakarta), Sekolah Tinggi Akuntansi Negara (STAN Jakarta), Universitas Gadjah Mada (UGM Yogyakarta), Institut Teknologi Bandung (ITB

\footnotetext{
${ }^{10}$ DPP Partai Keadilan, Sekilas Partai Keadilan (Jakarta: 1998 ), 12.

${ }^{11}$ Quran Chapter 13: 11.

${ }^{12}$ See Media Indonesia, July 26, 2005.

${ }^{13}$ Liqa a (لقي) literally means "meeting." This term is taken from the Arabic and used by PKS members to refer to weekly gatherings consisting of small groups (5-12 persons) to learn Islamic studies under the guidance of more senior and qualified Islamic teachers of PKS members called murabbi. Although generally they discuss Islamic teachings in this gathering, it is also used as a tool to strengthen cadre relationships among the party members.
} 
Bandung), Institut Pertanian Bogor (IPB Bogor), Institut Keguruan dan Ilmu Pendidikan (IKIP now UNJ Jakarta), Trisakti University Jakarta and other universities in Indonesia. The halaqah has succeeded in attracting university students to join the group. Students mostly with a non-Islamic studies background seem to find spiritual guidance in the halaqah. Their transitional personality from teenagers to becoming adult seems to encourage them to join this type of group. The halaqah groups approach university students, both male and female alike, persuasively and politely and this enables the groups to have big followings and become a mainstream movement in the universities mentioned above.

When the tarbiyah movement was transformed into the Islamic party called PKS, both university students and alumni actively involved in the tarbiyah movement now became the active members of the party and continued to use the halaqah style in recruiting and maintaining their members. They even further created what it called Multi Level Dakwah (MLD) which seems to be similar to the Multi Level Marketing (MLM) approach in business. The principle of this MLD was that each member should intensively approach their families or friends to participate firstly in halaqah activities and in the end attract them to join the party. This approach is also known as the cell theory of recruitment.

Strategies have been applied by PKS not only to spread out and recruit new members but also to maintain and develop their members' loyalty to the party by making regular cadre training such as liq $\bar{a}$, and muqayyam as part of halaqah and tarbiyah movements. Further, the PKS has implemented two pillars of their tarbiyah movement, which are straight manhaj $^{14}$ and qualified murabbi. ${ }^{15}$ While a leader of halaqah is called murabbi $\bar{i}$, the members themselves are called mutarabbi (guided students). Liqa' and muqayyam have been selected as good training to create solid and qualified cadres of PKS.

In the halaqah or liqa ${ }^{-}$program, PKS provides special curricula consisting of planning activities and materials that should be taught by murabbi to halaqah members. This curriculum was set up by the party, particularly by their division on cadres called Departemen Kaderisasi. For new members of PKS, a halaqah guideline is called Manajemen Tarbiyah Anggota Pemula (Tarbiyah Management for Beginner Members). In this guideline, the party set its tarbiyah curriculum as well. The curriculum covers four materials, which are 1) basic teachings of Islamic studies; 2) basic teachings of skills and self empowerment, 3) dakwah and Islamic thoughts, and 4) social sciences.

\footnotetext{
${ }^{14}$ Manhaj is taken from Arabic word literally meaning systematic steps to be followed to achieve an objective. Straight manhaj here refers to steps or programs that have been done and exemplified by the prophet Muhammad in his dakwah.

${ }^{15}$ Murabbi is taken from Arabic literally means an educator. It then refers to a leader in a group discussion (halaqah) who guides their members in Islamic teachings.
} 


\section{Student Networking Overseas}

To maintain the integrity of the members who are living or studying overseas and to expand its cadre membership, the PKS also maintains an international network. It is very common to see how PKS cadres, who are studying overseas, keep up their halaqah or tarbiyah activities. Different from other parties in Indonesia, the PKS has their branch overseas called PIP-PKS or Pusat Informasi dan Pelayanan PKS (The Information and Service Center of PKS). The PIP-PKS is not only involved in maintaining their cadres' mutual relations by performing liq $\bar{a}$ ' and other such activities, but is also active in disseminating PKS programs and ideas to Indonesians-students and workers alike--living overseas. The PIP-PKS can be found in Australia and New Zealand, Japan, Malaysia, Singapore, Egypt, United Kingdom and South America. ${ }^{16}$

\section{Big Family and Polygamy}

Although I cannot find any official documents of the party stating that PKS cadres should have a lot of children to increase the numbers of cadres and members, it is clear from almost all members of PKS I have met and interviewed, that they have or are planning to have as many children as they can. During the rally protests that I attended, as is also well known by the Indonesian public, PKS members would happily bring their children or even babies to come along with their parents, attending the rally protest organized by the party.

The following data on the number of children that parliament members from PKS have seem to support the argument that PKS members are more likely to have big family to fulfill their agenda of enlarging the numbers of cadres and members. I found that eighty two per cent (thirty seven out of forty five parliament members) from PKS have four children or more and only eighteen percent have two children or less. The general norm in Indonesia for numbers of children is having no more than three children. The data also show that the highest number of children of any PKS parliament member is thirteen, and this record is held by a female member, Yoyoh Yusroh. There are three female parliament members from PKS, namely, Yoyoh Yusroh (thirteen children), Aan Rohanah (eight children) and Nursanita Nasution (seven children). For PKS members, it is important to have huge numbers of children because they believe that family members could become the main pillar of cadres of the party.

Besides the idea of having big families, it is commonly assumed by Indonesian people that one of the PKS strategies to expand their

\footnotetext{
${ }^{16}$ Based on my observation in Kuala Lumpur during my fieldwork and in Singapore, these international networks are solid and have several activities to promote PKS's programs and to attract overseas Indonesian voters.
} 
membership is through polygamy. It is publicly known that practicing polygamy is popular among PKS cadres. According to Darol Mahmada, "Sementara sudah jadi rahasia umum kalau ikhwan partai ini (PKS) lazim melaksanakan praktek polygamy dengan tujuan untuk perluasan dakwah Islam" ${ }^{17}$ (It is no secret that it is common for PKS member to practice polygamy in order to expand their Islamic dakwah activity.) Although it is hard to get an official PKS document which states that polygamy is one of their strategies to expand their membership, the practice of polygamy among members of PKS particularly among leading figures of the party, is well known publicly. Several leading figures of the party who practiced polygamy are, for example, Tifatul Sembiring (President of the party), M. Anis Matta (Secretary General of the party), Hilmi Aminudiin (Head of Majlis Syuro PKS), Didin Amiruddin (Deputy Treasury of PKS) and Zulkieflimansyah (Parliament Member from PKS).

From the above explanation, we can say that PKS has a very intensive cadre's recruitment and trainings to enlarge membership and maintain their solidity. Thus, it is safe to argue that if we look at their solidity, it is understandable if PKS could have a huge support in the election. However, the questions are remained that to have a successful performance in the election, a solid cadre is not the only factor. The experience of PKS in the 2009 election which will be discussed below could proof this argument.

\section{B. Experience of PKS in 2009 Election}

The PKS's consistent adherence to democratic procedures can be seen from its continued participation in the last 2009 and forthcoming 2014 Indonesian elections. The support for PKS in the 2009 election was a disappointment for the party. PKS has failed to its ambition to gain at least 20 per cent of the vote. PKS's votes only slightly increased from 7.4 per cent in 2004 to 7.9 per cent in 2009.

The dynamics of the political situations Indonesia have influenced the performance of PKS in the last elections. The popularity of Susilo Bambang Yudhoyono's presidency has paved the way for Partai Demokrat (Democratic Party) to become the most successful party that has managed to gain 20.9 per cent of the votes in 2009. Yudhoyono's party defeated other big and established parties like the Golkar Party and the PDIP, Partai Demokrasi Indonesia Perjuangan (Indonesian Democratic Party of Struggle). Golkar, the most powerful party during Soeharto's era, dropped to only $14.5 \%$ compared to $21.6 \%$ of votes in 2004 election, and PDIP's Megawati party fell from $18.5 \%$ in 2004 to $14.0 \%$ in 2009. Although the performance of PKS is better in 2009 compared to that of in 2004, the

${ }^{17}$ N. Darol Mahmada, “Nabi Itu Monogami,” Gatra, December 5, 2007. 
performance of Islamic parties declined from $38.1 \%$ in 2004 to $27.8 \%$ in $2009 .{ }^{18}$ A detailed explanation of factors that contributed to PKS's relative failure in 2009 is provided below.

PKS Survival in 2009 Election?

The performance of Islamic political parties in the 2009 Indonesian election has attracted many comments from political analysts. The election shows the decline in support for Islamic parties except for PKS. Partai Kebangkitan Bangsa (Party of National Awakening) dropped from $10.6 \%$ in 2004 to $4.9 \%$ in 2009. Partai Persatuan Pembangunan (United Depelopment Party) dropped from $8.1 \%$ to $5.3 \%$, and other two Islamic parties Partai Bulan Bintang (PBB) and Partai Bintang Reformasi (PBR) failed to pass the $2.5 \%$ electoral threshold. PKS won about 7.9 per cent of votes and thus stood at the fourth rank after Yudhoyono's Democratic Party and other two secular parties, Golkar and PDIP. One could argue that PKS just managed to survive in the 2009 election.

Table 1: 2004 and 2009 Indonesian Elections Result

\begin{tabular}{|c|c|c|c|c|}
\hline Party & \multicolumn{2}{|c|}{2004} & \multicolumn{2}{|c|}{2009} \\
\hline & $\begin{array}{c}\% \text { of total } \\
\text { votes }\end{array}$ & $\begin{array}{l}\text { No. of } \\
\text { Seats }\end{array}$ & $\begin{array}{c}\% \text { of total } \\
\text { votes }\end{array}$ & $\begin{array}{c}\text { No. of } \\
\text { Seats }\end{array}$ \\
\hline Golkar Party & 21.6 & 128 & 14.4 & 108 \\
\hline PDIP & 18.5 & 109 & 14.0 & 93 \\
\hline PKB & 10.6 & 52 & 4.9 & 26 \\
\hline PPP & 8.1 & 58 & 5.3 & 39 \\
\hline Partai Demokrat & 7.4 & 57 & 20.80 & 148 \\
\hline PKS & 7.3 & 45 & 7.9 & 59 \\
\hline PAN & 6.4 & 52 & 6.0 & 42 \\
\hline Gerindra & -- & -- & 4.5 & 30 \\
\hline Hanura & -- & -- & 3.8 & 15 \\
\hline PDS & 2.13 & & & \\
\hline
\end{tabular}

Source: Adopted from the General Election Commission (KPU)

The failure of PKS to reach its target to at least gain $20 \%$ voters in the election was mostly due to external factors, mainly the popularity of Yudhoyono and his Democratic Party. The incumbent government under Yudhoyono presidency won a significant victory. Corruption becomes an important issue in the 2009 Indonesian election. Yudhoyono was perceived by Indonesians as 'a hero' who campaigned extensively for anti-corruption. During his first term in office, to combat corruption in Indonesia, Yudhoyono established two institutions, Komisi Pemberantasan Korupsi (Corruption Eradication Commission) and Pengadilan Tindak Pidana Korupsi (Corruption Court).

${ }^{18}$ Marcus Mietzner, Indonesia's 2009 Elections: Populism, Dynasties and the Consolidation of the Party System, Lowy Institute for International Policy, (Sydney 2009): 12. 
Another factor in Yudhoyono's success was his introduction of massive cash programs for the poor known as Bantuan Langsung Tunai (BLT) or Direct Cash handouts programs to help poor people in the country. Mietzner notes that the ruling government spent US\$2 billion between June 2008 and April 2009 (almost one year before the election). Yudhoyono's campaign was the government's compensation for the poor after his government had increased fuel prices. ${ }^{19}$

Besides the popularity of the Yudhoyono's government, Noorhaidi highlights three internally-driven factors that contributed to the disappointing result of PKS: wrong campaign strategy, failure to attract swing voters, and failure to portray itself as an outsider and reformist party. ${ }^{20}$

PKS's campaign to strengthen its image as a moderate Islamist party open to all segments of Indonesian society, both Muslim and nonMuslim, was a failure. PKS failed in its attempt to attract their non-cadre constituents although it offered a pluralist orientation to voters. Its approach even seems to be to lessen their support from both Muslim and non-Muslim alike. On the one hand, for Muslim voters, PKS's lesser emphasis on Islamic ideology made them curious about whether PKS had abandoned its Islamic agenda. For non-Muslims, on the other hand, this campaign was considered as only a rhetorical tactic or political strategy to attract voters to PKS.

The PKS campaign in printed media and television that praised Soeharto as 'a national hero' also contributed to its decline. While some saw this campaign as an opportunistic and pragmatic maneuver of PKS, others saw this pro-Soeharto move as making it difficult for PKS to stand on their own position as a reformist party. ${ }^{21}$

The PKS also failed to repeat its success in attracting the swing voters, as it did in 2004. According to Mietzner, significant electoral swing voters during the 2009 election have benefited the secular parties, particularly the Democratic Party. The decision of several Muslim socioreligious organization to join a variety of parties has also contributed to the decline of Islamic parties like PKS. ${ }^{22}$ PKS move to join Yudhoyono's ruling government (2004-2009) also brought another disadvantage for it. On the one hand, when the government was praised by the people for its success, it was easily claimed as the success of Yudhoyono's Democratic Party, instead of PKS. On the other hand, by joining the government, it was

\footnotetext{
${ }^{19}$ Marcus Mietzner, Indonesia's 2009 Elections: Populism, Dynasties and the Consolidation of the Party System, Lowy Institute for International Policy, (Sydney 2009): 4.

${ }^{20}$ Noorhaidi Hasan, "Islamist Party, Electoral Politics and Da'wa Mobilization among Youth: The Prosperious Justice Party (PKS) in Indonesia, RSIS Working Paper, Rajaratnam School of International Studies (Singapore 2009): 20-21.

${ }^{21}$ Mietzner, Indonesia's 2009 Elections, 14.

${ }^{22}$ Mietzner, Indonesia's 2009 Elections, 15.
} 
difficult for PKS to keep its image as an outsider party committed to total reform that had made it popular in the 2004 election.

PKS participation in the 2009 election provided us with some indicators in measuring the commitment of PKS to uphold democratic principles in achieving their objectives. The discussion above shows how the local political issues that appeared prior to the elections in the country greatly influenced the electoral performance of the party. The ruling government was portrayed by the people as a successful in combating corruption in the country, which made it difficult for PKS and other parties to compete with the ruling party. There was no alternative Indonesian political leader who could rival Yudhoyono's popularity and provide powerful leadership for the opposition. While Yudhoyono cannot be nominated for the third term of presidency, how would it impact to the performance of PKS in 2014 election?

\section{The Prediction of Survey Institution Prior to 2014 Election}

The latest survey done by Indonesian Survey Circle (LSI) showed that the performance of Islamic political parties including PKS in the coming election would be worse than previous elections. LSI found that if the election is held in the present days, none of the major Islamic political parties would remain among the top five parties. There will be no single Islamic parties got more than five percent of the voters.

Another survey institution like the National Survey Institute (LSN) found that not only support for the Islamic parties decline but also for the Islamic politicians. The survey done by LSN revealed low support for specific politicians from Islamic parties, such as Hidayat Nur Wahid (PKS), Hatta Rajasa (PAN), Muhaimin Iskandar (PKB) and Suryadharma Ali (PPP).

The above trends, according to Umar S Bakry (executive director of LSN), shows that it is not impossible that Islamic parties' performance like PKS will even drop deeper in the 2014 elections.

There are a variety of reasons for the declining popularity of Islamic political parties including PKS. LSI mentioned several factors which lead to the slide in support for Islamic political parties.

First, Indonesians may have doubt and less confidence in the capacity of Islamic parties to solve national problems compare to that of secular nationalist parties. For example, the problem of massive corruption cases in the country which is considered by Indonesian people as the first 'illness' that the country should eliminate, can not be solved by Islamic parties and Muslim politicians. The involvement of the former president of PKS, Luthfi Hasan Ishak, in the case of beef graft allegation has lessened the confidence of Indonesian people to the integrity of PKS in eradicating 
corruption in Indonesia. The arrest of PKS chairman Luthfi Hasan Ishaaq is a body blow for the party and will adversely affect its chances in 2014, analysts have predicted. Hanta Yuda from the Poll Tracking Institute, for example, said: that the PKS must search for other issues than anticorruption, because the public will no longer trust in its massive campaigns against it. Just like the Democratic Party, the PKS will automatically be associated with corruption after the investigation of Luthfi. The same as hanta Yuda, Burhanuddin Muhtadi, a political analyst with the Indonesian Survey Institute (LSI), said:

PKS was facing an existential crisis. "This case will also disorient party members, who have long had the impression that their leaders have been working very hard for them." ${ }^{23}$

The finding of Lembaga Survei Jakarta (LSJ) who held their survey on 9-15 February 2013 after the arrest of Luthfi Hasan Ishak also showed that only 6,9 percent among 1.225 respondents who will vote for Democratic Party in 2014 election and only 2,6 percent who will vote for PKS. According to Igor, a researcher from LSJ, the case of beef graft has impacted in declining trust of people to the PKS jargon as a clean party. Only 15,7 percent of respondent still believe that PKS is still a clean party, 66 percent did not believe anymore and 18,3 percent of respondents answered do not know. ${ }^{24}$ In addition, the fact that the popularity of Islamic political party, likes PKS decreases, has also proved that the phenomenon of Islam Yes, Islamic Political Parties No, is now seemed to be mushrooming and strengthening among Indonesian Muslims' belief. If this jargon promoted by Nurcholish Madjid in 1960s-1970s, was only 'a moral call', it is currently becoming a political reality. Indonesian people seem to believe that there is no difference between Islamic and nationalist parties in combating corruption in the country.

Second, Islamic political parties are commonly known to have a funding problem. Eighty five percents of the respondent, according to LSI, argue that Islamic parties including PKS are weaker in terms of funding resources compare to secular nationalist parties. Compare to nationalist parties such as Golkar, PDIP, Hanura, Gerindra and Nasdem, one would agree that Islamic parties such as PKS and PBB are very weak in term of their funding to face the coming 2014 election.

Third, the cases of radicalism in the name of religion in Indonesia have also led to the decline of Islamic political parties in the country. The violence actions done by some groups in the name of Islam have paved the

\footnotetext{
${ }^{23}$ The Jakarta Post, February 1, 2013.

${ }^{24}$ Prayitno Ramlan, "Menang di Pilkada Jabar dan Sumut, PKS Masih hebat atau Tersesat," in http//www. http://ramalanintelijen.net/?p=6530 (accessed September 10, 2013).
} 
way to the 'collective anxiety' and declining Islamic political parties' popularity including PKS in the eyes of the public.

Fourth, secular and nationalist parties seem to be more accommodative to the voters' Islamic aspirations. These secular parties have transformed themselves into secular-inclusive parties to accommodate the Islamic constituents. Voters with Islamic leanings now have a wider choice as they no longer have to depend on the Islamic parties to fight for their religious interests. Besides the four reasons above, the weak figure of PKS to be nominated as a president candidate and to attract voters outside PKS' cadres is another reason why PKS could not become a champion in the 2014 election.

Although in the coming 2014 election Yudhoyono will not contest for his third term, it is not easy for PKS to have an alternative Islamic Indonesian political leader who is high in popularity and powerful in leadership. The lose of Hidayat Nur Wahid in the Jakarta gubernatorial election was the example that the main figure of PKS was not supported by the people compare to that of nationalist leaders such as Joko Widodo. If Hidayat Nur Wahid, who was considered as one of the leading figures in PKS, was lose in the local election, one would assume that he was not popular enough to be nominated by PKS in the presidential election.

The factor of charismatic and popular leader as a significant factor in attracting the voters in Indonesia has been proven by the fact when Joko Widodo (Jokowi) was elected as a governor of DKI Jakarta in 2012. Based on the findings of current several surveys in Indonesia, one would agree that for the 2014 election there was no alternative Indonesian political leader who could rival Jokowi's popularity. Jokowi would replace the popularity of Yudhoyono who can not be nominated for the presidency in 2014. It is hard for Islamic political parties like PKS then to have or to create a figure like Jokowi while the election is approaching.

The West Java gubernatorial election was also strengthening the argument that figure is very important to attract the voters. Although PKS claimed that they have successful in West Java local election because their candidate, incumbent Ahmad Heryawan, was elected for the second term, it is publicly known that Heryawan and PKS political machinery were not the main factor for their success. The people of West Java believed that nomination of Dede Yusuf as a vice governor in the first term of Heryawan gubernatorial, was among the significant reason why the pair of HeryawanDede Yusuf has been elected. In addition, the nomination of Dedi Mizwar (a popular senior actor) as a vice governor in the last gubernatorial election was also the main factor why Heryawan was elected for the second terms. 


\section{Islamic Parties including PKS are Survivors, Surveys are Looser?}

Based on the quick count result done by several survey institutions, the best three of political parties in 2014 Indonesian election are PDIP (around 19\% of the vote), Golkar (14\%) and Gerindra (12\%). Although, these three nationalist parties are considered to be the champion of the legislative 2014 election, some argue that the performance of Islamic parties were not bad. PKB (Muslim based mass party) has increased dramatically from only 4 percent in 2009 election to get around 9 percent in the 2014 election, followed by PAN (7 \%), PKS (6-7 \%) and PPP (6-7 \%).

Table 2: Quick Count Result

\begin{tabular}{|l|l|l|l|l|l|l|}
\hline No. & \multicolumn{1}{|c|}{ Party } & IPI & LSI & CSIS & LSN & \multicolumn{1}{c|}{ RRI } \\
\hline 1. & PDIP & $19,40 \%$ & $19,74 \%$ & $19,10 \%$ & $20,77 \%$ & $18,58 \%$ \\
\hline 2. & Golkar & $14,43 \%$ & $14,59 \%$ & $14,44 \%$ & $13,58 \%$ & $14,64 \%$ \\
\hline 3. & Gerindra & $12,30 \%$ & $11,78 \%$ & $11,80 \%$ & $12,35 \%$ & $11,46 \%$ \\
\hline 4. & Demokrat & $9,74 \%$ & $9,12 \%$ & $9,60 \%$ & $10,65 \%$ & $10,26 \%$ \\
\hline 5. & PKB & $8,98 \%$ & $9,93 \%$ & $9,30 \%$ & $7,93 \%$ & $9,59 \%$ \\
\hline 6. & PAN & $7,34 \%$ & $7,05 \%$ & $7,40 \%$ & $7,53 \%$ & $7,44 \%$ \\
\hline 7. & PKS & $6,91 \%$ & $6,59 \%$ & $6,98 \%$ & $7,32 \%$ & $6,74 \%$ \\
\hline 8. & PPP & $6,34 \%$ & $7,32 \%$ & $6,60 \%$ & $6,89 \%$ & $6,52 \%$ \\
\hline 9. & Nasdem & $6,88 \%$ & $6,29 \%$ & $6,80 \%$ & $5,39 \%$ & $6,77 \%$ \\
\hline 10. & Hanura & $5,47 \%$ & $5,28 \%$ & $5,40 \%$ & $5,10 \%$ & $5,48 \%$ \\
\hline 11. & PBB & $1,54 \%$ & $1,38 \%$ & $1,60 \%$ & $1,45 \%$ & $1,65 \%$ \\
\hline 12. & PKPI & $0,94 \%$ & $1,02 \%$ & $1,10 \%$ & $1,04 \%$ & $0,94 \%$ \\
\hline
\end{tabular}

Source: Adapted from the several sources

(the website of survey institution and online news).

From the above table it is clear that Islamic political parties were survive enough in the election. The performance of these Islamic parties has reversed the prediction of survey institutions prior to 2014 election. For example, a survey done by Kompas and Lingkaran Survey Indonesia showed that PKB and PKS would not get huge support from the voters. A survey conducted by Kompas on January 9, 2014 showed that PKB would only get 4,1 to 5,1 percent of the voters. But in a reality, PKB has doubled its support up to around 10 percent according to quick count result. In addition, the LSI in their last survey released on February 2, 2014 mentioned that PKS would be one of four parties that could not pass 3 percent electoral threshold. ${ }^{25}$

The PKS popularity in this current election, one would argue, could be considered as a survivor. If many surveys said that PKS would be lucky if they can secure more than 5 percent of the vote, after the involvement of its former president in beef graft case, the party can secured just below 7 2014.

${ }^{25}$ See Palupi Annisa Auliani, "Partai Politik Berbasis Islam Menjungkirbalikkan Survei," Kompas, April 10, 
percent. However, the PKS was failing to reach their optimistic target to finish in the top three in the election. Before the election, party's elites believe that PKS could win a quite significant number of the votes. Even, the PKS president says: "We are confident that in the remaining 40 days, we can achieve much progress. We can do enough to allow us to rank in the top three positions, God willing (Insha Allah). ${ }^{26}$

\section{CONCLUSION}

From the above explanation, it is secured to argue that Islamic political parties, including PKS, are not the looser in the 2014 legislative election. PKS particularly has shown that they can maintain and strengthen their cadres' solidity. Their leading figures have successfully rebuilding trust not only for their loyal cadres but also public in general that they are really 'clean' and 'professional' and ready to combat corruption in the country. PKS has proved to the public that the case of their former president was 'the only corruption case' done by 'an oknum' that they will not tolerate.

Since the presidential election is approaching, PKS should gear up their party to build a coalition with other Islamic parties to nominate vice president or president in the July 9, 2014 presidential election. After surviving in the legislative election, it is a good opportunity for PKS to prove that they can play a significant role in the coming presidential election.

\section{REFERENCES}

Anwar, M. Syafi'i. "PKS's Vision and Strategy." Van Zorge Report (2004): 1.

Bastoni, Hepi Andi and Syaiful Anwar. Penjaga Nurani Dewan: Lebih Dekat Dengan 45 Anggota DPR RI Fraksi PKS. Bogor: Pustaka alBustan, 2006.

Collins, Elizabeth Fuller and Ihsan Ali Fauzi. "Islam and Democracy! The Successful New Party PKS is a Moderate Alternative to Radical Islamism.” Inside Indonesia (Jan-March 2005).

Damanik, Ali Said. Fenomena Partai Keadilan: Transformasi 20 Tahun Gerakan Tarbiyah di Indonesia. Jakarta: Teraju, 2002.

Dewan Pimpinan Wilayah PKS Jawa Barat. Menyelamatkan Bangsa: Platform Kebijakan Partai Keadilan Sejahtera. Bandung: Lajnah Pemenangan Pemilu DPP PKS, 2004.

DPP Partai Keadilan. Sekilas Partai Keadilan. Jakarta: 1998.

${ }^{26}$ See The Jakarta Post, March 2, 2014. 
--------. Manajemen Tarbiyah Anggota Pemula. Jakarta: Syaamil Cipta Media, 2004.

Furkon, Aay Muhamad. Partai Keadilan Sejahtera: Ideologi dan Praksis Politik Kaum Muda Muslim Indonesia Kontemporer. Jakarta: Teraju, 2004.

Hasan, Noorhaidi. "Islamist Party, Electoral Politics and Da'wa Mobilization among Youth: The Prosperious Justice Party (PKS) in Indonesia," RSIS Working Paper. Singapore: Rajaratnam School of International Studies, 2009.

Kamaruddin, Ada Apa Dengan Partai Keadilan Sejahtera: Catatan Dari Warga Universitas Indonesia. Jakarta: Pustaka Nauka, 2004.

Liddle, R. William and Saeful Mujani. "Indonesia in 2004: The Rise of Susilo Bambang Yudhoyono." Asian Survey, 45:1 (2005).

Machmudi, Yon. Partai Keadilan Sejahtera : Wajah Baru Islam Politik Indonesia. Bandung: Harakat una , 2005.

Mahmada, N. Darol. "Nabi Itu Monogami." Gatra, December 5, 2007.

Mietzner, Marcus. Indonesia's 2009 Elections: Populism, Dynasties and the Consolidation of the Party System. Sydney: Lowy Institute for International Policy, 2009.

Nurdin, Ahmad Ali. "Comparing the Ideology of PKS and Malaysia's PAS.” The Jakarta Post, November 28, 2005.

Sekretariat Jenderal DPP PKS Bidang Arsip dan Sejarah, Sikap Kami: Kumpulan Sikap Dakwah Politik PK dan PKS Periode 1998-2005. Bandung: Harakatuna Publishing, 2007.

Sembiring, Tifatul. "Preface" to Djony Edward, Efek Bola Salju Partai Keadilan Sejahtera. Bandung: Harakat una Publishing, 2006.

Wahid, Hidayat Nur. "Power Means Serving Others." Van Zorge Report, (March 18, 2002).

. "Islam, Democracy and Politics in Indonesia." The Jakarta Post, September 9, 2005.

Waluyo, Sapto. Kebangkitan Politik Dakwah: Konsep dan Praktik Politik Partai Keadilan Sejahtera di Masa Transisi. Bandung: Harakatuna, 2005.

Zulkieflimansyah. "Overcoming the Fear: PKS and Democratization." The Jakarta Post, December 13, 2005.

. "Prospects for the Justice and Prosperity Party (PKS) and Political Islam." USINDO Open Forum. Washington DC, June 8, 2006. 